\title{
Spatial and temporal distribution of fish larvae in marginal lagoons of Pantanal, Mato Grosso State, Brazil
}

\author{
Karina Keyla Tondato ${ }^{1,2}$, Lúcia Aparecida de Fátima Mateus ${ }^{3}$ and Simoni Ramalho Ziober ${ }^{1}$
}

An analysis was made of the spatial and temporal distribution of the abundance and composition of fish larvae assemblies, aiming to ascertain correlations with biotic and abiotic factors in marginal lagoons of the Cuiabá River floodplain in Brazil's Pantanal wetlands. Samples were collected bimonthly in the pelagic region of the marginal lagoons (fourteen lagoons) close to the littoral zone covered by aquatic macrophytes from December 2006 to April 2007. The captured individuals consisted of 2,739 larvae, represented predominantly by Triportheus spp. (Characidae), Parodontidae, Anostomidae, Characidae and Serrasalmidae. Larval density varied among the sample lagoons in December, but the biotic (zooplankton density) and abiotic (water temperature, electrical conductivity, dissolved oxygen, $\mathrm{pH}$, water transparency and lagoon depth) factors did not significantly affect larval composition and abundance. Larvae were captured throughout the sample period, with the highest densities occurring in December and early January. Temporally, lagoon depth, water transparency and fluviometric level showed a negative correlation with larval density. Both the zooplankton and the larval density vary positively, responding likewise to the environmental conditions imposed by flooding. The highest larval density was also found to coincide with the first rains (early December), when the rainfall has not yet reached its peak.

Foi realizada uma análise da distribuição espaço-temporal da abundância e composição da assembleia de larvas de peixes, com o objetivo de verificar as correlações com os fatores bióticos e abióticos em lagoas marginais da planície de inundação do rio Cuiabá, Pantanal, Brasil. As amostras foram coletadas quinzenalmente na região pelágica das lagoas, perto da zona litorânea coberta por macrófitas aquáticas, de dezembro de 2006 à março de 2007, na planície de inundação. Foram capturadas 2.739 larvas, representadas predominantemente por Triportheus spp. (Characidae), Parodontidae, Anostomidae, Characidae e Serrasalmidae. A densidade de larvas variou entre as lagoas amostradas em dezembro, mas as variáveis bióticas (densidade de zooplâncton) e abióticas (temperatura da água, condutividade elétrica, oxigênio dissolvido, $\mathrm{pH}$, transparência e profundidade da lagoa) não afetaram significativamente a composição e a abundância das larvas. As larvas foram capturadas ao longo de todo o período de amostragem, com maiores densidades no mês de dezembro e início de janeiro. Temporalmente, a profundidade da lagoa, a transparência e o nível fluviométrico mostraram uma correlação negativa com a densidade de larvas. Tanto a abundância de zooplâncton, quanto à abundância de larvas variaram positivamente, respondendo da mesma forma às condições ambientais impostas pela cheia. A maior densidade de larvas coincidiu com as primeiras chuvas (início de dezembro), quando a pluviosidade ainda não tinha atingido seu pico.

Key words: Ichthyoplankton, Floodplain, Cuiabá River, Natural nurseries.

\section{Introduction}

The majority of fishes that spawn annually reproduce during the period of the year when the environmental conditions are the most favorable for the survival of their offspring, especially in terms of food supply and habitat availability (Welcomme, 1979; Castro et al., 2002). Many species migrate during the reproductive period, seeking suitable locations for egg fertilization and development of the offspring (Welcomme, 1985), while others live in and develop all their life cycle in the same environment (Vazzoler, 1996). However, their reproductive behavior varies among environments and they are widely dependent on local environmental factors (Humphries et al., 1999; Pouilly \& Rodriguez, 2003). Therefore, biotic (food availability, presence of predators, and competition) and abiotic factors (physical and chemical variables), or their interaction, may determine the season and suitableness of habitat accessible for

\footnotetext{
${ }^{1}$ Programa de Pós-Graduação em Ecologia e Conservação da Biodiversidade, Instituto de Biociências, Universidade Federal de Mato Grosso, 78.060-900 Cuiabá, MT, Brazil.

${ }^{2}$ Programa de Pós-Graduação em Biologia Animal, Instituto de Biociências, Universidade Federal do Rio Grande do Sul. Av. Bento Gonçalves, 9500, prédio 43435, sala 104, 91501-970 Porto Alegre, RS, Brazil. ktondato@hotmail.com

${ }^{3}$ Laboratório de Ecologia e Manejo de Recursos Pesqueiros, Instituto de Biociências, Universidade Federal de Mato Grosso. Av. Fernando Corrêa da Costa s/n, CCBS-II/Anexo, Coxipó, 78.060-900 Cuiabá, MT, Brazil.1mateus@ufmt.br
} 
reproductive success (Harvey, 1991; Scheidegger \& Bain, 1995), producing variations in ichthyoplankton distribution patterns (Sanvicente-Añove et al., 2000; Bialetzki et al., 2005; Ramos et al., 2006).

In temperate environments it has been demonstrated that changes in the reproductive period of fish species are closely related with variations in the photoperiod, water temperature and food availability (Munro, 1990; Lowe-McConnell, 1999). The spawning period appears to be linked primarily to the production cycles of zooplankton (Cushing, 1990; SanvicenteAñove et al., 2006), of which Rotifera, Copepoda and Cladocera are the most important components (Milstein et al., 2006). In contrast, in tropical environments, the rise of the water level and increased rainfall are considered determining factors in the reproductive seasonalness of fish (MachadoAlisson, 1990; Vazzoler, 1996; Lowe-McConnell, 1999).

In the floodplains of Brazil, information about the ecology of ichthyoplankton has concentrated on the upper Paraná River (Nakatani et al., 1997; Bialetzki et al., 2004). In this environment, the greatest larval densities are observed between October and March (Baumgartner et al., 1997), and the increase in the photoperiod (Baumgartner et al., 1997), rising temperature (Castro et al., 2002), variations in the direction and flow of water (Bialetzki et al., 1999), rise in water level, and high rainfall (Nakatani et al., 1997) are the factors that most influence distribution of ichthyoplankton. In addition, some studies propose spatial and temporal relationships between the ichthyoplankton and the community of zooplankton (Baumgartner et al., 1997; Bialetzki et al., 1999, 2005), although only a few of them quantify these relationships (Reynalte-Tataje, 2007).

Several studies have demonstrated that the floodplain of the Cuiabá River is one of the main breeding sites of fishes in Pantanal (Lourenço et al., 2008), but there is a scarcity of studies that confirm the reproductive activity to help shed light about the influence of environmental factors on the distribution of the ichthyoplankton community of this region (Severi, 1997; Santin, 2007). Such studies are fundamental, since variations in larval distribution patterns reflect changes that affect the distribution of adult fish and traits of reproductive strategies, such as spawning time, duration and sites (Doyle et al., 1993; Nonaka et al., 2000). Moreover, this is a possible tool for the establishment of actions in fishing management and preservation of areas of reproductive activity (King et al., 2003). In this context, the purpose of the present study was to characterize the taxonomic composition and perform the first analyses of distribution and abundance of the assemblies of fish larvae in marginal lagoons in the floodplain of the Cuiabá River, as well as to answer the following questions: 1) Is there a spatial and/or temporal difference, during the flooding phase, in the abundance and composition of fish larvae in marginal lagoons of the Cuiabá River? 2) Does the biotic and abiotic factors in marginal lagoons of the Cuiabá River determine the spatial and temporal distribution of abundance and composition of fish larvae, during the flooding phase?

\section{Material and Methods}

\section{Study Area}

The Pantanal is an immense floodplain which is part of the upper Paraguay River basin, covering an area of approximately $140,000 \mathrm{~km}^{2}$. The alternation between rainy and dry seasons defines the climate as seasonal, presenting pluriannual variability, i.e., alternating cycles of very wet and very dry years (Hamilton et al., 1996).

The region's hydrological regime can be divided into four periods: high waters (January to March), low waters (April to June), dry season (July to September) and rising waters (October to December). The period of rising waters is marked by the beginning of the rains and the resulting rise in the water level of the Cuiabá River (da Silva \& Esteves, 1995), followed by the period of high waters, where the rivers overflow, invading the floodable areas.

Along the banks of the lower portion of the Cuiabá River there is a complex of marginal lagoons. These lagoons are permanent water bodies which contain water during the dry season and are strongly influenced by the seasonal variation in the river's water level and by the fluctuations of the water level during the flooding period. Some of these lagoons are connected directly to the river channel, while others are linked through drainage channels (temporary channels that connect the lagoon to the river). Their size, depth and water flow speed vary, and they present a vast cover of aquatic macrophytes which are represented predominantly by the species Eichornia azurea, Eichornia crassipes and Salvinia sp.

The region under study is located in the Reserva Particular do Patrimônio Natural of SESC Pantanal (RPPN SESC Pantanal), between the meridians of $56^{\circ}$ and $57^{\circ}$ and the parallels $16^{\circ}$ and $17^{\circ}$, in a site known as the Pantanal of Poconé, which is part of the Cuiabá River basin that drains an area of approximately $20,000 \mathrm{~km}^{2}$, and is located about 145 kilometers away from the municipality of Cuiabá, in the State of Mato Grosso. A total of 14 lagoons were sampled, situated along the right and left banks of the Cuiabá River (Fig. 1).

\section{Samplings and data analysis}

The fish larvae were collected in the pelagic region close to the littoral zone covered with aquatic macrophytes. Three sampling points were selected in each lagoon, as follows: entrance (1), middle (2) and end (3). Point 3 of each lagoon was standardized as the side opposite to the lagoon's entrance. Two additional sampling points were selected only in the lagoons that presented drainage channels: entrance to the channel (1.1), and end of the channel (1.2), and these points were only used to graphically analyze the spatial distribution within each lagoon. Sampling was carried out every fortnight, between December 2006 and April 2007, coinciding with the end of the rising waters, high waters, and beginning of the low waters in the Pantanal, i.e., almost the entire flood phase. The collections were realized during daylight, between 7:00 a.m. and 6:00 p.m., because it was not possible to standardize the time, due to logistics. 


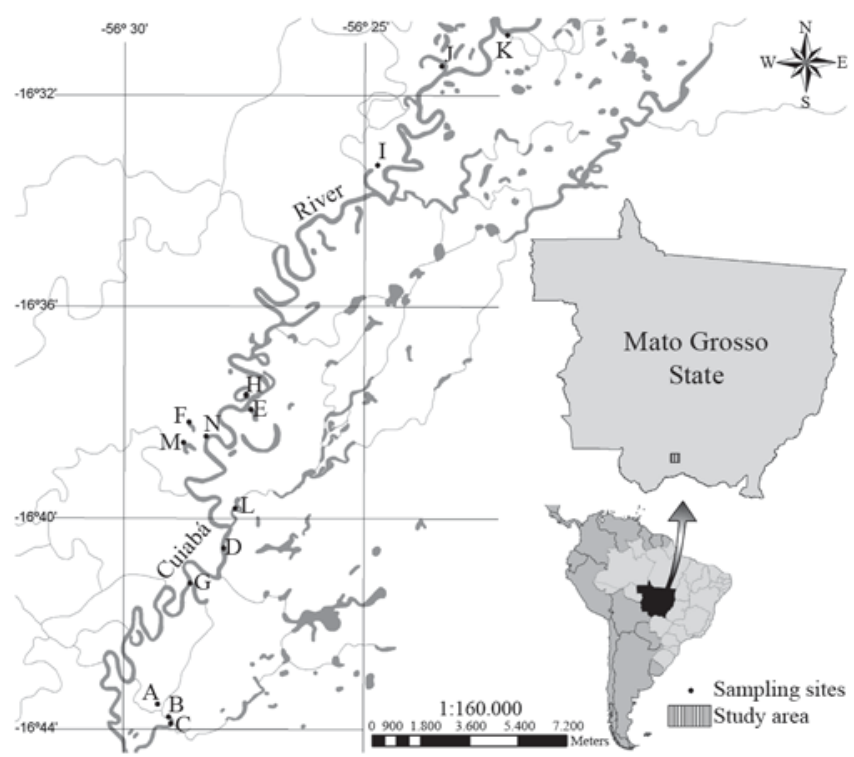

Fig. 1. Location of sampling sites in the floodplain of Cuiabá River, Pantanal, Mato Grosso State, Brazil.

The ichthyoplankton samples were collected using a cylindrical plankton net of $300 \mu \mathrm{m}$ mesh, 1.5 meters tall, with an opening of $18.095 \mathrm{~m}^{2}$ and a cup adapted to the bottom end. A flow meter was fixed to the opening of the net to estimate the volume of water filtered. The net was stabilized in a metal structure held up by floats. This structure has a lever fixed to the side of the boat and equipped with cables which pulls the dragnet horizontally through the water. A standard drag of 3 minutes was employed at the water's subsurface (approximately $20 \mathrm{~cm}$ deep) at each point in the lagoon, so, the sum of the drag time of these 3 points in each lagoon totalizes 9 minutes.

The collected material was fixed in $4 \%$ formalin with sodium chloride ( $14 \mathrm{~g} / \mathrm{L}$ of formalin). The identification, which was based on morphometric and meristic characteristics, was carried out at the lowest possible taxonomic level, according to Nakatani et al. (2001). Some of larvae were identified only at order or family levels, and the individuals identified at lower taxonomic levels that belonged to these groups, were counted separately for the analysis. After the identification, the specimens were separated according to four stages of development: yolk-sac, preflexion, flexion and post-flexion, according to the terminology described by Ahlstrom \& Moser (1976), and modified by Nakatani et al. (2001). For the larval abundance analyses, a standard volume of $10 \mathrm{~m}^{3}$ of filtered water was used, as described by Tanaka (1973).

To estimate the density of the zooplankton community (biotic factor), samples were collected at point 3 of each lagoon. Each collection involved filtering $200 \mathrm{~L}$ of subsurface water through a $45 \mu \mathrm{m}$ mesh plankton net, using a $20 \mathrm{~L}$ bucket. The samples were stored in $50 \mathrm{ml}$ flasks and fixed in 4\% formalin. Using Sedgewick Rafter chambers, the zooplankton density was estimated by counting $3 \mathrm{ml}$ subsamples removed with a conventional pipette. The density was expressed in individuals per cubic meter (ind $/ \mathrm{m}^{3}$ ).

The abiotic factors of water temperature $\left({ }^{\circ} \mathrm{C}\right), \mathrm{pH}$, dissolved oxygen $(\mathrm{mg} / \mathrm{L})$ and electrical conductivity $(\mu \mathrm{S} / \mathrm{cm})$ were measured at each sampling point with the help of electronic sensors. The water transparency and depth at the sampling points were measured simultaneously using a Secchi disk. The precipitation and fluviometric levels of the Cuiabá River were supplied by SESC-Pantanal and obtained from the Porto Cercado station in the Mato Grosso.

\section{Spatial analysis}

Spatial distribution was analyzed based on the sampling of December, when the largest capture of larvae occurred. A graphic analysis was made to evaluate spatial differences in the distribution of larvae density by points and by stages of development in each lagoon (including the additional points of drainage channels, when present), and also to evaluate the differences in taxonomic composition (the most abundant taxa) among the sampled lagoons.

For the other spatial (i.e., among lagoons) and temporal analyses, the larval densities were considered according to the point grouping (1,2 and 3 ) in each lagoon in order to increase the variability. A graphic analysis was made to evaluate the spatial difference in larval density among the sampled lagoons. To analyze the distribution of larvae in relation to the density of zooplankton, only the density of larvae that could present feeding activity were used, i.e., those that were in the same or in more advanced stages of development than preflexion.

To evaluate the correlation between fish larvae density and composition and the environmental conditions (abiotic and biotic factors) in the sampled lagoons, the abiotic factors (water temperature, electrical conductivity, dissolved oxygen, $\mathrm{pH}$, transparency and depth of the lagoon) were first transformed into $\log (\mathrm{x}+1)$ (except for the $\mathrm{pH}$ ) because they have distinct units of measure. Then, the multidimensionality of these variables was reduced using Principal Component Analysis (PCA), considering the 11 lagoons sampled in December (3 lagoons were inaccessible in this month). The PCA axes with eigenvalues higher than 1.0 were accepted for interpretation, according to the Kaiser-Guttman criterion (Jackson, 1993). Only variable with loadings higher than 0.7 were considered as formers of the PCA axes (Comrey \& Lee, 1992). A Pearson correlation was then drawn up to analyze the correlation between the abiotic factors and the zooplankton density in the sampled sites. In this analysis, we used the scores of the PCA axes accepted for interpretation as explanatory variables and the logarithms of zooplankton density as descriptive variables.

Multiple regression was used to analyze the effect of associated (correlated) or isolated abiotic and biotic factors on the determination of larvae density, using as explanatory variables the PCA axes (abiotic factors) and the logarithm of zooplankton density (biotic factor), and as the response variable the logarithm of larval density. To evaluate the effect of the abiotic factors and zooplankton density (biotic factor) on the composition of fish larvae, we began by carrying out a Non-metric Multidimensional Scaling (NMDS) (McCune \& 
Grace 2002; Costa et al., 2009) in order to reduce the composition of the assemblies in one dimension. We then performed a multiple regression, considering the axis of the NMDS as the descriptor variable and zooplankton density and abiotic factors (represented by the PCA axes) as the explanatory variables. The PCA, Pearson correlation and multiple regressions were carried out with the help of the Systat (Wilkinson, 1998) program, while the NMDS was performed using the PC-ORD (McCune \& Mefford, 1999).

\section{Temporal Analysis}

To evaluate the relationship between larval densities and abiotic factors and zooplankton density among the sampled periods, a Pearson correlation was employed. The logarithm of the mean larval and zooplankton densities and the logarithms of the abiotic factors were considered to draw this correlation. In addition, to analyze the influence of zooplankton density by group (Rotifera, Copepoda and Cladocera) on the larval density among the periods, the relationship was examined graphically. A nonlinear regression was made between the larval density and the variable of transparency and precipitation. Because these factors were not linear in the relationship, they were adjusted using an exponential model.

\section{Results}

\section{Ichthyoplankton taxonomic composition}

Throughout the sampling period, 2,739 larvae belonging to three orders were captured: Characiformes, Siluriformes and Gymnotiformes (Table 1). The order Characiformes contributed to $94.23 \%$ of the total number, while the Siluriformes and Gymnotiformes together contributed $0.47 \%$. Unidentified and damaged larvae amounted to $5.29 \%$ of the total. Despite the limitations and difficulties involved in identifying the taxonomic groups, the Characiformes comprised 12 taxa belonging to 4 families, with Characidae showing the highest contribution, i.e., 7 taxa. The five most abundant taxa were Triportheus spp. (Characidae), Parodontidae, Anostomidae, Characidae and Serrasalmidae, respectively. No larvae of migratory species were captured except for a single individual of Brycon sp.

\section{Spatial distribution}

Larval density varied among sites in December. The highest larval densities occurred predominantly in lagoons A (5.28 larvae $\left./ 10 \mathrm{~m}^{3}\right), \mathrm{B}\left(2.6\right.$ larvae $\left./ 10 \mathrm{~m}^{3}\right)$ and $\mathrm{I}\left(2.05\right.$ larvae $\left./ 10 \mathrm{~m}^{3}\right)$ (Fig. 2), and the highest densities were found at points 1 and 3 of the lagoons (Fig. 3a). No evident difference was found in the composition of the four most abundant taxa among the lagoons in this period. With the exception of lagoons $\mathrm{F}$ and $\mathrm{G}$, which presented only 'unidentified' or 'damaged' larvae, the other lagoons showed the presence of the same taxa (Fig. 3b). The larvae in the preflexion stage (represented by frequency of occurrence) represented $92.98 \%$ of the total of the four stages sampled in December (Fig. 3c). No individuals were captured in lagoons $\mathrm{H}$ and $\mathrm{N}$ in this sampling.

\section{Effect of biotic and abiotic factors on the spatial distribution of fish larvae abundance and composition}

The density of zooplankton collected in December was approximately 70,000 individuals $/ \mathrm{m}^{3}$, with $66.20 \%$ (46,320 ind/ $\mathrm{m}^{3}$ ) of the specimens represented by Rotifera, followed by Copepoda with $33.75 \%\left(23,612 \mathrm{ind} / \mathrm{m}^{3}\right)$ and Cladocera with only $0.05 \%\left(34 \mathrm{ind} / \mathrm{m}^{3}\right)$. Total zooplankton density among the lagoons in December varied from $0 \mathrm{ind} / \mathrm{m}^{3}$ (lagoon B) to 46,125

Table 1. Taxonomic groups and fish larvae densities (larval density $/ 10 \mathrm{~m}^{3}$ ) captured in the marginal lagoons along the Cuiabá River, Pantanal of Mato Grosso. *Larvae identified only at the order level; **Larvae identified only at the family level.

\begin{tabular}{|c|c|c|c|c|c|c|c|c|c|}
\hline \multirow{2}{*}{ Taxonomic groups } & \multicolumn{9}{|c|}{ Periods } \\
\hline & $\mathrm{D}$ & $\mathrm{J} / 1$ & $J / 2$ & $\mathrm{~F} / 1$ & $F / 2$ & $\mathrm{M} / 1$ & $\mathrm{M} / 2$ & A & Sum \\
\hline Characiformes* & 0.092 & 0.595 & 0.068 & 0.026 & 0 & 0.030 & 0 & 0.138 & 0.949 \\
\hline Characidae** & 2.044 & 0.678 & 0.119 & 0.102 & 0.021 & 0.030 & 0 & 0.061 & 3.055 \\
\hline Triportheus spp. & 4.703 & 1.464 & 0.010 & 0.028 & 0 & 0 & 0.061 & 0 & 6.266 \\
\hline Aphyocharax spp. & 0.033 & 0 & 0.006 & 0 & 0 & 0 & 0.030 & 0.030 & 0.099 \\
\hline Brycon spp. & 0 & 0 & 0 & 0.003 & 0 & 0 & 0 & 0 & 0.003 \\
\hline Bryconamericus spp. & 0.085 & 0 & 0.010 & 0.010 & 0 & 0 & 0 & 0 & 0.105 \\
\hline Moenkhausia spp. & 0.036 & 0 & 0 & 0.009 & 0.003 & 0.030 & 0 & 0 & 0.078 \\
\hline $\begin{array}{l}\text { Myloplus sp. } \\
\text { Lebiasinidae }\end{array}$ & 0 & 0.012 & 0.003 & 0 & 0 & 0 & 0 & 0 & 0.015 \\
\hline Pyrrhulina autralis & 0.015 & 0.006 & 0.012 & 0.009 & 0.011 & 0.030 & 0.030 & 0.076 & 0.189 \\
\hline Serrasalmidae** & 0.036 & 1.203 & 0.201 & 0 & 0 & 0 & 0 & 0 & 1.44 \\
\hline Anostomidae** & 2.621 & 0.380 & 0.035 & 0.096 & 0 & 0 & 0 & 0 & 3.132 \\
\hline Parodontidae** & 3.137 & 0.098 & 0.024 & 0.019 & 0 & 0 & 0.085 & 0.092 & 3.455 \\
\hline Siluriformes* & 0 & 0.036 & 0 & 0.020 & 0 & 0 & 0 & 0 & 0.056 \\
\hline $\begin{array}{l}\text { Pimelodus spp. } \\
\text { Cetopsidae }\end{array}$ & 0.006 & 0.015 & 0 & 0 & 0 & 0 & 0 & 0 & 0.021 \\
\hline Cetopsis gobioides & 0 & 0.015 & 0 & 0 & 0 & 0 & 0 & 0 & 0.015 \\
\hline Callichtyidae** & 0 & 0.012 & 0 & 0 & 0 & 0 & 0 & 0 & 0.012 \\
\hline Gymnotiformes & & & & & & & & & \\
\hline Sternopygidae** & 0 & 0 & 0.004 & 0 & 0 & 0 & 0 & 0 & 0.004 \\
\hline Unindentified & 0.319 & 0.042 & 0.003 & 0.016 & 0.005 & 0.030 & 0.018 & 0 & 0.433 \\
\hline Damageds & 0.500 & 0.058 & 0 & 0.005 & 0.003 & 0 & 0 & 0 & 0.566 \\
\hline Sum & 13.627 & 4.614 & 0.495 & 0.343 & 0.043 & 0.150 & 0.224 & 0.397 & \\
\hline
\end{tabular}




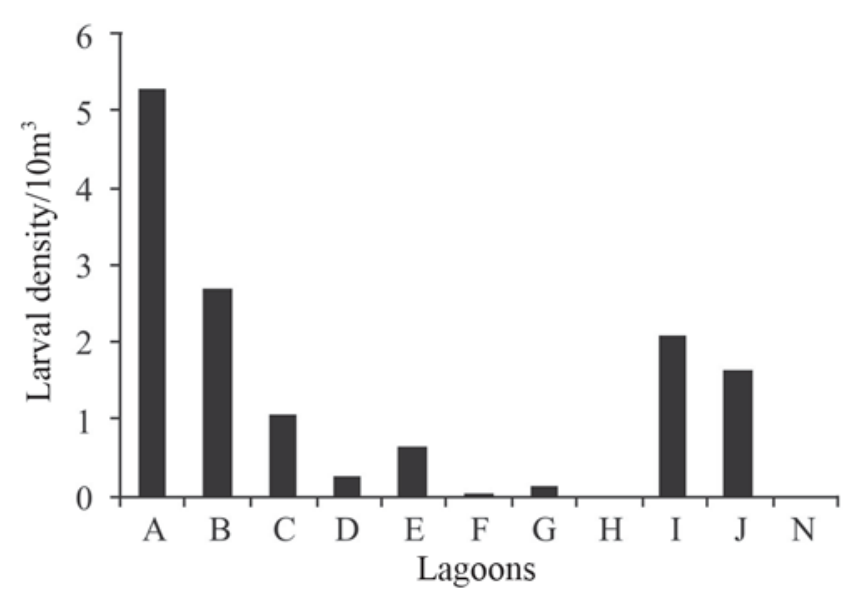

Fig. 2. Spatial distribution of fish larvae in marginal lagoons along the Cuiabá River in December 2006.

ind $/ \mathrm{m}^{3}$ (lagoon F) (Table 2).

The abiotic factors also showed spatial variations in December, with lagoon depths varying from $0.6 \mathrm{~m}$ (lagoon $\mathrm{N}$ ) to $3.7 \mathrm{~m}$ (lagoon E). Similarly, water transparency varied from $0.18 \mathrm{~m}$ (lagoon F) to $1.17 \mathrm{~m}$ (lagoon $\mathrm{H}$ ). Electrical conductivity was found to oscillate from $20.6 \mu \mathrm{S} / \mathrm{cm}$ (lagoon F) to $73.56 \mu \mathrm{S} /$ $\mathrm{cm}$ (lagoon A). The values of dissolved oxygen varied from $3.07 \mathrm{mg} / \mathrm{L}$ to $8.71 \mathrm{mg} / \mathrm{L}$ in lagoons $\mathrm{H}$ and $\mathrm{B}$, respectively. The $\mathrm{pH}$ showed a slight variation, with a minimum of 5.83 (lagoon F) and a maximum of 6.73 (lagoon $\mathrm{N}$ ), as the water temperature, which varied from $27.86^{\circ} \mathrm{C}$ (lagoon F) to $33.13^{\circ} \mathrm{C}$ (lagoon J) (Table 2).

The reduction of the dimensionality of the abiotic factors in December, which was determined through Principal Components Analysis (PCA), captured $47.68 \%$ (eigenvalue: 2.861 ) of the variability of the data on the first axis. The factors that presented a relation to the first axis were $\mathrm{pH}(0.708)$, temperature $(0.780)$ and conductivity $(0.869)$. The second axis captured $24.10 \%$ (eigenvalue: 1.446 ) of the variation, and only water transparency was related to this axis. The Pearson correlation applied to the PCA scores and the logarithms of zooplankton density presented no significant effect with any of the axes, showing PCA $1(p=0.547)$ and PCA $2(p=0.105)$. Thus, the multiple regression model was applied using the PCA axes 1 and 2 (abiotic factors) and zooplankton density as explanatory variables and larval density as the response variable. The combined effect of these factors on larval density in December was not significant $\left(\mathrm{F}_{3 ; 7}=0.970 ; \mathrm{R}^{2}=\right.$ $0.29 ; \mathrm{p}=0.459)$, nor were PCA $1(\mathrm{p}=0.661)$, PCA $2(\mathrm{p}=0.219)$ and zooplankton density $(\mathrm{p}=0.944)$.

The ordering of the sites sampled in December, based on the composition of fish larvae species explained $71.9 \%$ of the original data. The joint effect of the abiotic factors (PCA 1 and 2) and of the zooplankton density on the fish larvae composition ( $\left(1^{\text {st }} \mathrm{NMDS}\right.$ axis $)$ was not significant $\left(\mathrm{F}_{3 ; 4}=2.104\right.$; $\left.\mathrm{R}^{2}=0.61 ; \mathrm{p}=0.242\right)$. Similarly, PCA $1(\mathrm{p}=0.104)$, PCA $2(\mathrm{p}=$ $0.974)$ and zooplankton density $(p=0.341)$ showed no significant effect on the larval composition.

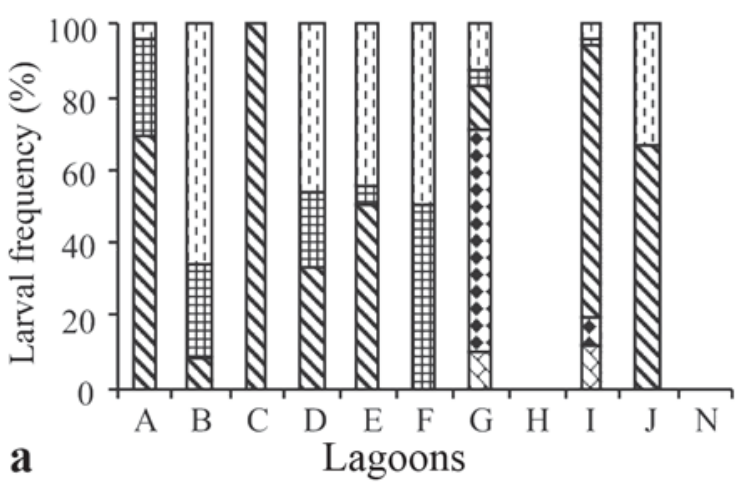

$\triangle$ Site $1.1 \square$ Site $1.2 \square$ Site 1 刃Site 2 DSite 3
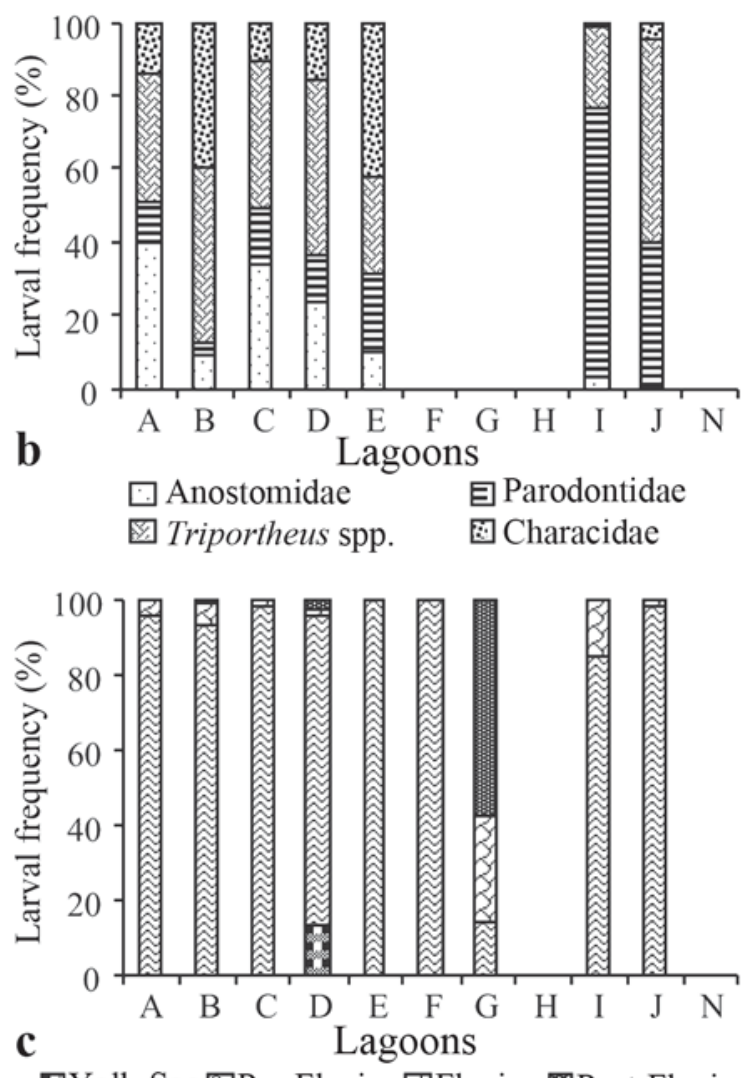

Yolk-Sac 图Pre-Flexion@Flexion 圈Post-Flexion

Fig. 3. Spatial distribution of fish larvae in marginal lagoons along the Cuiabá River in December 2006 as a function of: (a) Sampling point $(1=$ entrance, $2=$ middle, $3=$ end of lagoon, $1.1=$ entrance of channel and $1.2=$ end of channel, only in lagoons that present this characteristic); (b) Frequency of occurrence of the four taxa with the highest densities; and (c) Developmental stages.

\section{Temporal Distribution}

Fish larvae were captured during the entire sampling period, with the highest densities occurring in December (13.63 larvae/ $\left.10 \mathrm{~m}^{3}\right)$ and early January $\left(4.62\right.$ larvae $\left./ 10 \mathrm{~m}^{3}\right)$. A lower density $\left(0.04\right.$ larvae $\left./ 10 \mathrm{~m}^{3}\right)$ was found in late February (Fig. 4).

Characiformes were present throughout the period of this study, with a substitution of groups and variation in densities 
Table 2. Variation of the abiotic e biotic factors in marginal lagoons along the Cuiabá River in December 2006. Mean values by lagoon; ${ }^{\mathrm{a}}$ Minimum; ${ }^{\mathrm{b}}$ Maximum.

\begin{tabular}{cccccccc}
\hline Lagoons & $\begin{array}{c}\text { Electrical } \\
\text { Conductivity } \\
(\mu \mathrm{m} / \mathrm{S})^{*}\end{array}$ & $\begin{array}{c}\text { Dissolved } \\
\text { Oxygen } \\
(\mathrm{mg} / \mathrm{L})^{*}\end{array}$ & $\begin{array}{c}\text { Water } \\
\text { Temperature } \\
\left({ }^{\circ} \mathrm{C}\right)^{*}\end{array}$ & $\begin{array}{c}\text { Water } \\
\text { Transparency } \\
(\mathrm{m})^{*}\end{array}$ & $\mathrm{pH}$ & $\begin{array}{c}\text { Lagoon } \\
\text { Depth } \\
(\mathrm{m})^{*}\end{array}$ & $\begin{array}{c}\text { Density } \\
\text { Zooplankton } / \mathrm{m}^{3}\end{array}$ \\
\hline $\mathrm{A}$ & $73.56^{\mathrm{b}}$ & 6.25 & 28.40 & 0.41 & 6.50 & 1.75 & 1.466 \\
$\mathrm{~B}$ & 53.83 & $8.71^{\mathrm{b}}$ & 29.53 & 0.29 & 6.58 & 1.45 & $0^{\mathrm{a}}$ \\
$\mathrm{C}$ & 53.00 & 6.02 & 29.90 & 0.28 & 6.60 & 1.85 & 733 \\
$\mathrm{D}$ & 56.10 & 3.80 & 29.83 & 0.61 & 6.40 & 2.20 & 2.433 \\
$\mathrm{E}$ & 58.60 & 5.36 & 30.43 & 0.47 & 6.64 & $3.70^{\mathrm{b}}$ & 1.766 \\
$\mathrm{~F}$ & $20.60^{\mathrm{a}}$ & 6.95 & $27.86^{\mathrm{b}}$ & $0.18^{\mathrm{a}}$ & $5.83^{\mathrm{a}}$ & 0.65 & $46.125^{\mathrm{b}}$ \\
$\mathrm{G}$ & 50.50 & 7.46 & 28.43 & 0.74 & 6.21 & 1.60 & 4.316 \\
$\mathrm{H}$ & 63.26 & $3.07^{\mathrm{a}}$ & 29.16 & $1.17^{\mathrm{b}}$ & 6.33 & 1.35 & 3.850 \\
$\mathrm{I}$ & 60.40 & 4.21 & 29.40 & 0.48 & 6.14 & 2.45 & 2.700 \\
$\mathrm{~J}$ & 56.46 & 5.25 & $31.13^{\mathrm{a}}$ & 0.58 & 6.46 & 2.30 & 6.516 \\
$\mathrm{~N}$ & 62.36 & 4.38 & 29.63 & 0.47 & $6.73^{\mathrm{b}}$ & $0.60^{\mathrm{a}}$ & 55 \\
\hline
\end{tabular}

observed during the samplings (Table 1). A higher density of Triportheus spp. was observed in December and early January, but the density of this group diminished in late January, when there was a predominance of the subfamily Serrasalmidae. In early February, Serrasalmidae was not captured and the Characidae and Anostomidae families showed higher densities. At the end of February and in early March, only larvae of the family Characidae were captured, but in late March and early April, this taxon was replaced predominantly by the family Parodontidae (Fig. 5).

\section{Effect of biotic and abiotic factors on the temporal distribution of fish larvae abundance}

During the sampling periods, most of the factors showed oscillations, except for water temperature and $\mathrm{pH}$. The highest mean temperature value was recorded in early March, $31.93^{\circ} \mathrm{C}$, and the lowest in late February, $28.66^{\circ} \mathrm{C}$. The $\mathrm{pH}$ varied from 6.04 in late January to 7.32 in April. The variable of electrical conductivity varied from $55.29 \mu \mathrm{S} / \mathrm{cm}$ in December to 36.54

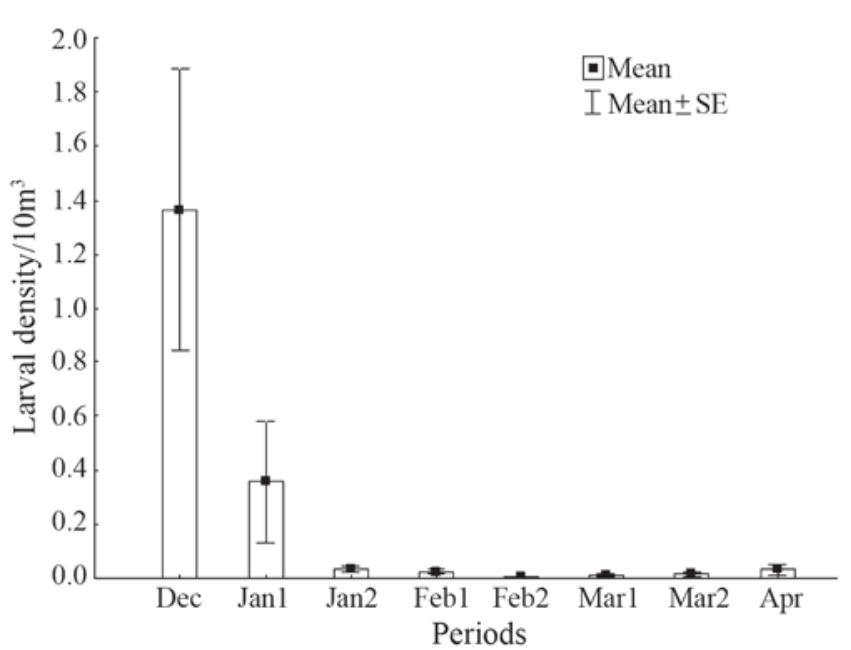

Fig. 4. Temporal distribution of fish larvae in marginal lagoons along the Cuiabá River between December 2006 and April 2007. $\mu \mathrm{S} / \mathrm{cm}$ at the end of February. As for dissolved oxygen, the mean values varied from $5.59 \mathrm{mg} / \mathrm{L}$ in December to $1.63 \mathrm{mg} / \mathrm{L}$ in January. Mean water transparency in the lagoons ranged from $0.519 \mathrm{~m}$ in December to $1.90 \mathrm{~m}$ in April. Similarly, the mean lagoon depth was lowest in December, $1.80 \mathrm{~m}$, and highest in April, $3.441 \mathrm{~m}$. Alterations were also observed in rainfall, whose highest value was recorded in January (225 $\mathrm{mm}$ ) and lowest in April (6 mm), while the fluviometric level of the Cuiabá River was lowest in December $(2.66 \mathrm{~m})$ and at its peak in early March (4.4 m). A decline in zooplankton density was also recorded along the periods, with the lowest value $\left(\sim 8,600 \mathrm{ind} / \mathrm{m}^{3}\right)$ occurring precisely at the beginning of March, the period of the greatest depth of the Cuiabá River.

The correlation between the abiotic and biotic factors and the logarithm of mean larval density in the sampled periods indicates that lagoon depth $(r=-0.985 ; p=0.000)$, fluviometric level $(\mathrm{r}=-0.959 ; \mathrm{p}=0.001)$ and zooplankton density $(\mathrm{r}=0.899$; $\mathrm{p}=0.006)$ significantly affected the density of larvae captured along the periods (Figs. 6a-c). Water transparency was also

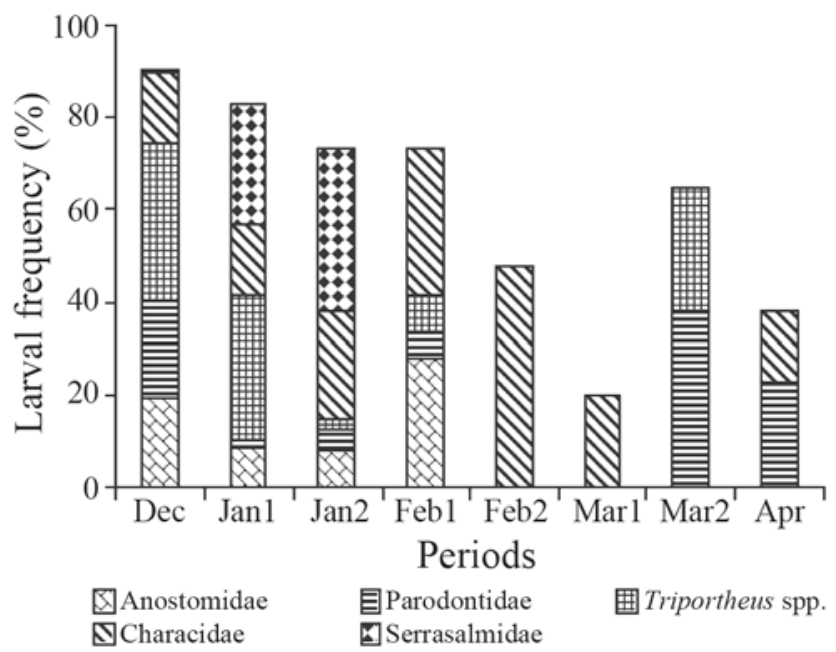

Fig. 5. Temporal distribution of the five taxonomic groups with the highest densities in marginal lagoons along the Cuiabá River between December 2006 and April 2007. 

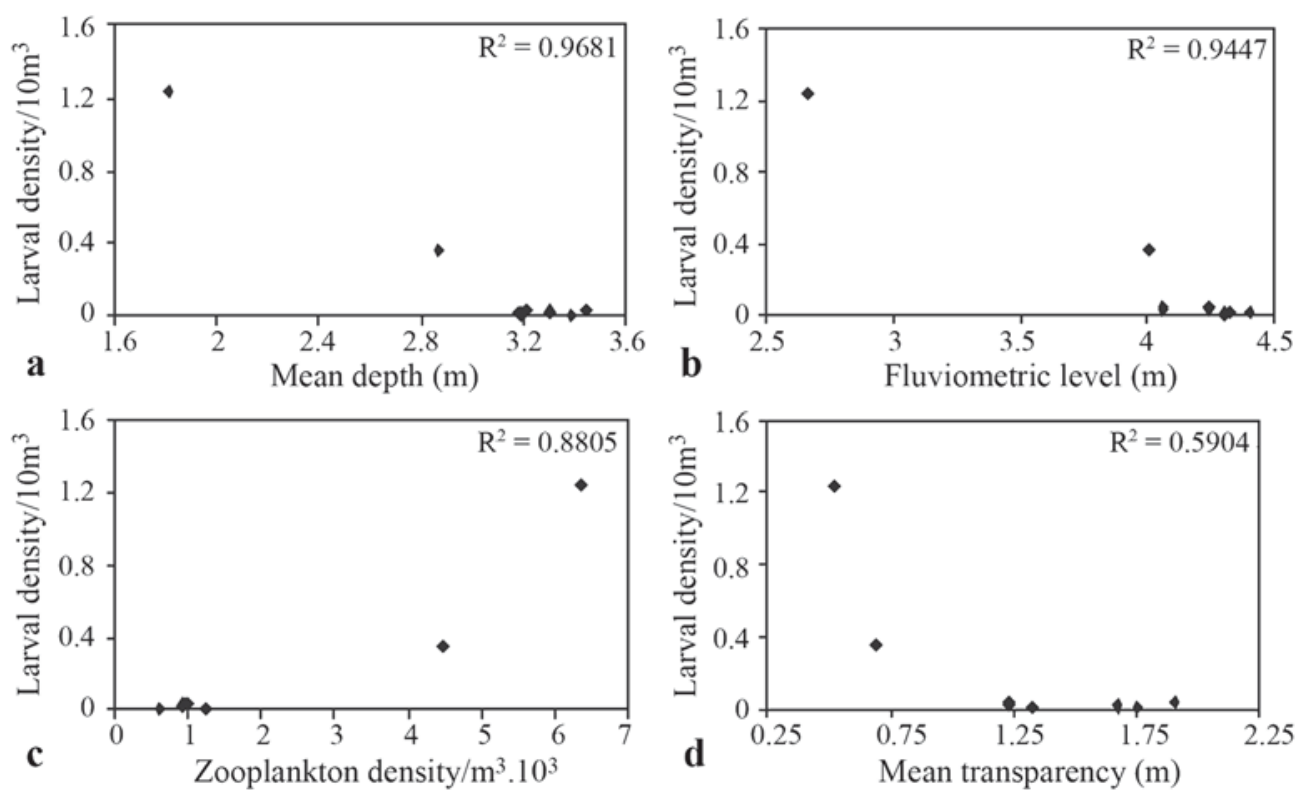

Fig. 6. Correlation of the mean density of fish larvae with: (a) Mean depth of the lagoons during the sampled periods; (b) Fluviometric level of the Cuiabá River during those periods; (c) Mean zooplankton density during those periods; and (d) Mean water transparency of the lagoons during the sampling periods.

found to affect mean larval density in the periods of this analysis, showing a negative exponential relation $(\mathrm{y}=$ $1.9016 \mathrm{e}^{-2.9735 x} ; R^{2}=0.5904$ ) (Fig. 6d).

No relationship was found between the mean density of captured larvae and precipitation $\left(y=0.0126 \mathrm{e}^{0.0115 x} ; \mathrm{R}^{2}=0.1855\right)$ in the sampling periods, but the highest larval density occurred precisely during the first rains (early December), when precipitation is not yet at its highest (Fig. 7). A correlation was detected between the mean larval density and the zooplankton groups Rotifera and Copepoda, indicating a covariation between the mean density of these groups and the mean density of larvae (Fig. 8).

\section{Discussion}

The larvae found in the marginal lagoons belonged mainly to taxa that represent small and medium-sized sedentary species, with a predominance of Characiformes. These small species are usually peculiar to lentic environments, developing all their life cycle in the floodplain (Castro et al., 2002). They have a long spawning period and are considered opportunists (Vazzoler, 1996). In their studies of fish communities in lagoons in the Pantanal wetlands, Súarez et al. (2004) and Baginski et al. (2007) found that these lagoons are inhabited primarily by small species and Characiformes. According to these authors, this is probably due to the distinct ecological strategies of each species. Hence, the behavioral or morphological adaptations of this group possibly provide favorable conditions for greater success of occupation in this environment. At the same time, collections made only at the surface of the water and in the daytime may have limited the capture of Siluriformes during this study. Baumgartner et

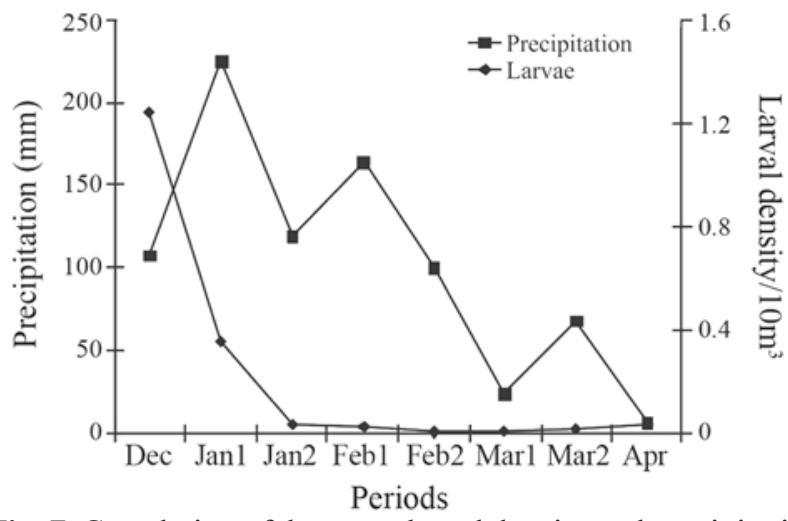

Fig. 7. Correlation of the mean larval density and precipitation in marginal lagoons along the Cuiabá River between December 2006 and April 2007.

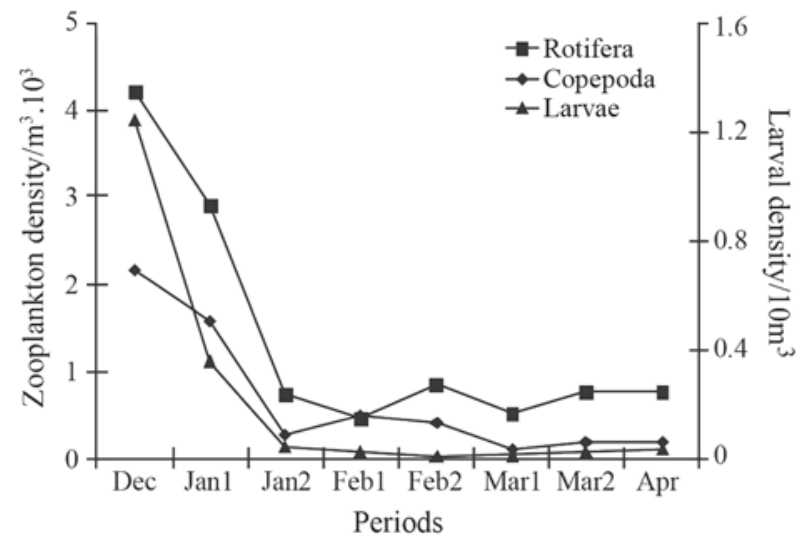

Fig. 8. Mean fish larvae density as a function of Rotifera and Copepoda density in marginal lagoons along the Cuiabá River between December 2006 and April 2007. 
al. (1997) found higher larval densities of Characiformes at the surface and of Siluriformes in the substrate. Although Siluriformes usually inhabit the substrate (Delariva et al., 1994), many of their species and other groups remain strategically at the bottom during the day to protect themselves from predators, migrating to the surface in search of food at night (Chambers \& Trippel, 2001).

A temporal succession was observed in the distribution of taxa, predominated initially by Triportheus spp. and subsequently replaced by Serrasalmidae, Characidae and Parodontidae, respectively. Serrasalmidae responded specifically and intensely to the environmental stimuli in January, while Characidae showed greater reproductive flexibility to environmental conditions and were present in practically all the periods of this study. This difference in densities indicated that taxa possess distinct reproductive strategies, responding differently to changes in environmental factors. Variability in spawned population size, availability of specific habitats required by each species, differences in predation pressure on eggs (Corbett \& Powles, 1986) and interspecific relationships are possible factors that determine density differences. Moreover, the structure of larval assemblages is the result of the adults' spawning behavior patterns, since they try to reproduce only in adequate conditions in order to achieve maximum reproductive success and ensure the survival of the largest number of offspring (Bialetzki et al., 2005).

Another factor to be considered is the predominance of larvae in the initial stage of development (preflexion stage) in almost all lagoons (with exception the lagoons $\mathrm{H}$ and $\mathrm{N}$, that present no capture) during December. In a study of nychthemeral cycles, Bialetzki et al. (1998) observed that Apareiodon affinis larvae in preflexion and flexion stages were captured only during the day, indicating a possible association of low visual acuity and greater swimming ability to avoid capture or intraspecific competition. Therefore, the large capture of larvae in this stage may be related with the daytime collections, the morphology characterized by the developmental stage itself, or behavioral changes of larvae or of adult spawning as a consequence of specific biotic and abiotic relationships in each environment. Furthermore, the presence of larvae in initial stages of preflexion characterize reproduction sites or their proximity (Petry, 1989), indicating that the reproduction sites of the captured species, when they do not occur in the lagoon itself, are possibly in transition sites between the lotic and lentic environments, e.g., in the river channel close to the entrance to the lagoons.

Knowing that lentic floodplain environments are important areas of reproduction of many migratory species (Welcomme, 1985), the absence of larvae of these species in the marginal lagoons points to the influence of three possible factors: 1) inefficiency of the sampling method; 2) non-adaptability to environmental conditions, which may often be unfavorable or intolerable for fecundation and larval development, compromising the reproductive success (Bialetzki et al., 2005); and 3 ) the larvae of migratory species may reach these habitats in advanced stages, using the lagoons only as growth sites. However, the large number of Characiformes that could not be identified may have included long-distance migratory species.

In the floodplain of the upper Paraná River, Nakatani et al. (1997) found higher larval densities in the mouth of the tributaries, indicating a preference of some species for sites with faster moving water. In this study, the highest larval densities were found at point 1 (entrance) of each lagoon, even those that had points 1.1 and 1.2 (drainage channels). Hence, our findings suggest that biotic or abiotic effects occurring in the river directly influence the entrance to the lagoons or, in some cases, the transitory conditions due to the presence of drainage channels, favoring spawning in these sites.

In an analysis of fish larvae in a reservoir system in North America, Quist et al. (2004) reported that the ichthyoplankton frequently displayed a spatially and temporally irregular distribution. In lentic freshwater systems, this distribution may reflect a response to predation, prey resources (Johnston et al., 1995) or drift, due to the movement of the waters (AraújoLima \& Oliveira, 1998), responding spatially to the local characteristics of each lagoon (Hayes et al., 1996). In the present study, we found that larvae occurred in practically all the sampled lagoons, but the spatial distribution among them was heterogeneous, suggesting that lagoons A, B and I, which showed the highest densities, have higher reproductive activity in December. However, environmental conditions such as zooplankton density and abiotic factors did not determine the larval densities of the marginal lagoons, indicating that the environmental variability among the lagoons does not suffice to determine the spatial distribution of the ichthyoplankton, which is related randomly to habitats with similar environmental conditions.

On the other hand, studies conducted in the floodplain of the Orinoco River in Venezuela have shown that, despite the considerable fluctuation of the waters in response to flooding, it is possible to predict the structure of the communities (Rodriguez \& Lewis, 1994), which are presumably altered and determined by local factors (Pouilly \& Rodriguez, 2003). Nevertheless, in the present work, the structure of larval communities was also not determined spatially by zooplankton density or abiotic factors operating separately or jointly. Therefore, this finding indicates that the variation in the environmental conditions analyzed in the lagoons does not suffice to determine reproductive intensity according to the taxonomic groups in the period analyzed.

Despite the presence of larvae throughout the sampling period, the highest larval density occurred in December (flood phase), involving massive spawning with large numbers of individuals in a relatively short period of time. In a study of the reproductive dynamics of Moenkhausia sanctaefilomenae in marginal lagoons along the Cuiabá River, Lourenço et al. (2008) found females of this species with mature gonads in December. Similarly, in the subbasin of the Miranda River in the southern Pantanal, higher larval densities were found in the months of November to February (Nascimento \& Nakatani, 2005), which are all hydrological moments of the beginning of high waters. 
Therefore, in the sampled period, the reproduction peak found in December reinforces the assumption that the reproduction of most of the floodplain species is highly seasonal, coinciding with the initial flood phases, as reported by Welcomme (1979).

In a study of the Australian floodplain, King et al. (2003) reported that, for a good recruitment, the fish should reproduce when the water level and temperature rise synchronously. Similarly, Vazzoler \& Menezes (1992) demonstrated that, in the Amazon and Paraná basins, the beginning of reproduction corresponds to the period when flooding begins and temperature rises, reaching peaks in reproductive activity when the two factors simultaneously reach their highest annual values. In the environment studied here, we found that the larval density displayed a marked temporal variation, its peak coinciding with the lowest values of fluviometric level, depth and water transparency in the lagoons. This finding indicates a strategic reproductive behavior of the sedentary species in response to flooding, enabling the December larvae to be in more advanced stages at flood peak in relation to the larvae of future spawns, minimizing predation and maximizing dispersion and the use of food. In addition, the decline in larval densities capture along the flood phase is probably due to the flood regime, when there is an expansion of the flooded area, elevating the volume of water in the lagoons and, consequently, increasing their depth. This process makes more habitats and microhabitats available, possibly maximizing the dispersion of larvae to other water bodies, diluting the planktonic organisms in the lagoons and resulting in a lower probability of capture, as reported in a study of fish by Baginski et al. (2007). At the same time, the increased water transparency facilitates visual predation of many fish, possibly leading to higher larval mortality over time.

The Match-Mismatch hypothesis also implies that the fish spawning period could be connected to the period of production cycles, establishing a link between the spawning period and seasonal production peaks, thereby ensuring the necessary food for a higher rate of survival and growth (Cushing, 1990). However, the relationship between fish spawning patterns and the cycle time of annual plankton production has not been clearly established, and controversies still remain (Sanvicente-Añorve, 2006).

In the present study, the positive correlation between larval and zooplankton densities in the sampled periods indicates that these two attributes co-vary, responding similarly to changes in the environmental conditions imposed by flooding and are probably not directly dependent. In a study of the ichthyoplankton distribution in the Ivinhema River, Reynalte-Tataje (2007) likewise found no significant correlation between the zooplankton and ichthyoplankton densities, but observed that, during the reproductive period, the peak of zooplankton organisms in the environment (December) coincided with the peak of larval density. However, in the Pantanal, low zooplankton densities were recorded in the period of high waters (Neves et al., 2003; Fantin-Cruz et $a l$., in press), and the flood phase was not the period of highest zooplankton density in this environment. The decline in zooplankton is probably due to lower food availability in high waters, since there is a reduction in the productivity of the system (Fantin-Cruz et al., in press). Considering this relationship, the larval density could also diminish over time due to the decline in zooplankton density, even though they are simultaneously affected by flooding.

In summary, marginal lagoons are important reproduction sites for many sedentary species of the floodplain of the Cuiabá River. Larval abundance varies spatially, but composition does not. At the same time, the spatial distribution of larval composition and abundance was not determined by zooplankton availability or by abiotic factors operating in the lagoons, which showed a random spatial pattern. Temporal differences in abundance were observed, with marked reproductive activity and higher densities in December coinciding with the first rains, higher zooplankton densities, lower fluviometric levels, transparency and depth of the lagoons.

The results of this study point to the need to question and investigate in greater detail the influence of zooplankton and abiotic factors on these communities. Moreover, the hypothesis should be proposed that the first rains, more than flooding and food availability, would act as master factors in the reproduction of many sedentary species in this floodplain. This knowledge and further studies such as research into reproductive biology are urgent priorities for improvements and guidance in environmental handling and management practices in this region.

\section{Acknowledgements}

The authors gratefully acknowledge the Centro de Pesquisa do Pantanal (CPP)/MCT and PELD/CNPq site-12 and the SESC Estação Ecológica Pantanal for their financial, human and logistic support. CAPES is acknowledged for providing a master's grant to the author. We are indebted to Simoni Loverde's team and Ibraim Fantin for their analysis of the zooplankton.

\section{Literature Cited}

Ahlstrom, E. H. \& H. G. Moser. 1976. Eggs and larvae of fishes and their role in systematic investigations and in fisheries. Revue des Travaux de L'Institut des Peches Maritimes, Nantes: 40(3/ 4): 379-398.

Araújo-Lima, C. A. R. M. \& E. C. Oliveira. 1998. Transport of larval fish in the Amazon. Journal of Fish Biology, 53(A): 297-306.

Baginski, L. J., A. C. Florentino, I. M. Fernandes, J. M. F. Penha \& L. A. de F. Mateus. 2007. A dimensão espacial e temporal da diversidade de peixes da zona litoral vegetada de lagoas marginais da planície de inundação do rio Cuiabá, Pantanal, Brasil. Biota Neotropica, 7(3): 1-6.

Baumgartner, G., K. Nakatani, M. Cavicchioli \& M. S. T. Baumgartner. 1997. Some aspects of the ecology of fishes larvae in the floodplain of the high Paraná River, Brazil. Revista Brasileira de Zoologia, 14(3): 551-553. 
Bialetzki, A., K. Nakatani, P. V. Sanches \& G. Baumgartner. 2004. Eggs and larvae of the "curvina" Plagioscion squamosissimus (Heckel, 1840) (Osteichthyes, Sciaenidae) in the Baía River, Mato Grosso do Sul State, Brazil. Journal of Plankton Research, 26(11): 1327-1336.

Bialetzki, A., K. Nakatani, P. V. Sanches, G. Baumgartner \& L. C. Gomes. 2005. Larval fish assemblage in the Baía River (Mato Grosso do Sul State, Brazil): temporal and spatial patterns. Environmental Biology of Fishes, 73: 37-47.

Bialetzki, A., P. V. Sanches, G. Baumgartner \& K. Nakatani. 1998. Caracterização morfológica e distribuição temporal de larvas de juvenis de Apareiodon affinis (Steindachner 1879) (Osteichthyes, Parodontidae) no alto do rio Paraná (PR). Revista Brasileira de Zoologia, 15(4): 1037-1047.

Bialetzki, A., P. V. Sanches, M. Cavicchioli, G. Baumgartner, R. P. Ribeiro \& K. Nakatani. 1999. Drift of ichthyoplankton in two channels of the Paraná River, between Paraná and Mato Grosso do Sul States, Brazil. Brazilian Archives of Biology and Technology, 42: 53-60.

Castro, R. J., K. Nakatani, A. Bialetzki, P. V. Sanches \& G. Baumgartner. 2002. Temporal distribution and composition of the ichthyoplankton from Leopoldo's Inlet on the upper Paraná River floodplain (Brazil). Journal of Zoology, 256: 437-443.

Chambers, R. C. \& E. A. Trippel. 2001. Early life history and recruitment in fish populations. $1^{\text {st }}$ Edition. Great Britain, Chapman \& Hall, 516p.

Comrey, A. L. \& H. B. Lee. 1992. A first course in factor analysis. $2^{a}$ edition. Hillsdale, Lawrence Erlbaum Associates.

Corbett, B. W. \& P. M. Powles. 1986. Spawning and larva drift of sympatric walleyes and white suckers in an Ontario stream. Transactions of the American Fisheries Society, 115: 41- 46.

Costa, F. R. C., J. L. Guillaumet, A. P. Lima \& O. S. Pereira. 2009. Gradients within gradients: The mesoscale distribution patterns of palms in a central Amazonian forest. Journal of Vegetation Science, 20: 69-78.

Cushing, D. H. 1990. Plankton production and year-class strength in fish populations: an update of the match/mismatch hypothesis. Advances in Marine Biology, 26: 249-293.

Delariva, R. L., A. A. Agostinho, K. Nakatani \& G. Baumgartner. 1994. Ichthyofauna associated to aquatic macrophytes in the upper Paraná River floodplain. Revista Unimar, 16(3): 41-60.

Doyle, M. J., W. W. Morse \& A. W. Kendall. 1993. A comparison of larval fish assemblages in the temperate zone of the northeast Pacific and northwest Atlantic oceans. Bulletin of Marine Science, 53: 588-644.

Fantin-Cruz, I., S. M. Loverde-Oliveira, C. C. Bonecker, P. Girard $\&$ D. M. Marques. (in press). Relation between the structure of the zooplankton community and the water level in a lake in the Pantanal floodplains of Mato Grosso, Brazil. Acta Scientiarum, Biological Sciences.

Hamilton, S. K., S. J. Sippel \& J. M. Melack. 1996. Inundation patterns in the Pantanal of South America determined from passive microwave remote sensing. Archiv Fur Hydrobiologie, 137(1): 1-23.

Harvey, B. C. 1991. Interaction of abiotic and biotic factors influences larval fish survival in an Oklahoma stream. Canadian Journal of Fisheries Aquatic Sciences, 48: 1476-1480.

Hayes, D. B., C. P. Ferreri \& W.W. Taylor. 1996. Linking fish habitat to their population dynamics. Canadian Journal Fisheries Aquatic Sciences, 53(Suppl. 1): 383-390.
Humphries, P., A. J. King \& J. D. Koehn. 1999. Fish, flows and flood plains: links between freshwater fishes and their environment in the Murray-Darling river system, Australia. Environmental Biology of Fishes, 56: 129-151.

Jackson, D. A. 1993. Stopping rules in principal components analysis: a comparison of heuristical and statistical approaches. Ecology, 74: 2204-2214.

Johnston, T. A., M. N. Gaboury, R. A. Janusz \& L. R. Janusz. 1995. Larval fish drift in the Valley River, Manitoba: influence of abiotic and biotic factors, and relationships with future yearclass strengths. Canadian Journal of Fisheries and Aquatic Sciences, 52: 2423-2431.

King, A. J., P. Humphries \& P. S. Lake. 2003. Fish recruitment on floodplains: the roles of patterns of flooding and life history characteristics. Canadian Journal of Fisheries and Aquatic Sciences, 60: 773-786.

Lourenço, L. S., L. A. F. Mateus \& N. G. Machado. 2008. Sincronia na reprodução de Moenkhausia sanctaefilomenae (Steindachner) (Characiformes: Characidae) na planície de inundação do rio Cuiabá, Pantanal Mato-Grossense, Brasil. Revista Brasileira de Zoologia, 25(1): 20-27.

Lowe-McConnell, R. H. 1999. Estudos ecológicos de comunidades de peixes tropicais. São Paulo, Edusp, 534p.

Machado-Alisson, A. 1990. Ecologia de los Peces de las áreas inundables de los llanos de Venezuela. Interciência, 15(6): 411-423.

McCune, B. \& J. B. Grace. 2002. Analysis of Ecological Communities. Gleneden Beach, Oregon MjM software design, 300p.

McCune, B. \& M. J. Mefford. 1999. PC-ORD v. 4. Multivariate analysis of ecological data. Gleneden Beach, Oregon, MjM Software Design.

Milstein, A., A. Valdenberg \& S. Harpaz. 2006. Fish larvaezooplankton relationships in microcosm simulations of earthen nursery ponds. I. Freshwater system. Aquaculture International, 14: 231-246.

Munro, A. D. 1990. General introduction. Pp. 1-11. In: Munro, A. D., A. P. Scotta \& T. J. Lam (Eds.). Reproductive seasonality in teleosts: environmental influences. Flórida, CRC Press, 254p.

Nakatani, K., A. A. Agostinho, G. Baumgartner, A. Bialetzki, P. V. Sanches, M. C. Makrakis \& C. S. Pavanelli. 2001. Ovos e larvas de peixes de água doce: desenvolvimento e manual de identificação. Maringá, Eduem, 378p.

Nakatani, K., G. Baumgartner \& M. Cavicchioli. 1997. Ecologia de ovos e larvas de peixes. Pp. 201-306. In: Vazzoler, A. E. A. de M., A. A. Agostinho \& N. S. Hahn (Eds.). A planície de inundação do alto Rio Paraná: Aspectos físicos, biológicos e econômicos. Maringá, Eduem, 460p.

Nascimento, F. L. \& K. Nakatani. 2005. Variação temporal e espacial de ovos e larvas de espécies de interesse para a pesca na sub-bacia do rio Miranda, Pantanal, Estado do Mato Grosso do Sul, Brasil. Acta Scientiarum, Biological Sciences, 27: 251-258.

Neves, I. F., K. F. Rocha \& A. A. Pinto. 2003. Zooplankton community structure of two marginal lakes of the river Cuiabá (Mato Grosso, Brasil) whith analysis of Rotifera and Cladocera diversity. Brazilian Journal of Biology, 63(2): 329-343.

Nonaka, R. H., Y. Matsuura \& K. Suzuki. 2000. Seasonal variation in larval fish assemblages in relation to oceanographic conditions in the Abrolhos Bank region off eastern Brazil. Fishery Bulletin, 98: 767-784.

Petry, P. 1989. Deriva do ictioplâncton no Paraná do Rei, várzea do Careiro, Amazônia Central, Brasil. Unpublished MSc. Thesis, Instituto Nacional de Pesquisas da Amazônia/Fundação Universidade do Amazonas, Manaus, 68p. 
Pouilly, M. \& M. A. Rodriguez. 2003. Determinism of fish assemblage structure in neotropical floodplain lakes: influence of internal and landscape lake conditions. Pp. 243-265. In: Welcomme, R. L. \& T. Petry (Eds.). Proceedings of the Second International Symposium on the Management of Large Rivers for Fisheries, Volume 2. Food and Agriculture Organization of the United Nations \& Mekong River Commission, FAO Regional Office for Asia and the Pacific. Bangkok, RAP Publication 2004/17, 310p.

Quist, M. C., K. R. Pember \& C. S. Guy. 2004. Variation in larval fish communities: implications for management and sampling designs in reservoir systems. Fisheries Management Ecology, 11: 107-116.

Ramos, S., R. K. Cowen, C. Paris, P. Ré \& A. A. Bordalo. 2006. Environmental forcing and larval fish assemblage dynamics in the Lima River estuary (northwest Portugal). Journal of Plankton Research, 28(3): 275-286.

Reynalte-Tataje, D. A. 2007. Influência inter e intra anual de variáveis ambientais sobre a estrutura da comunidade ictioplanctônica em duas bacias hidrográficas brasileiras. Unpublished $\mathrm{PhD}$. Thesis, Universidade Estadual de Maringá, Maringá, 122p.

Rodriguez, M. A. \& W. M. Lewis. 1994. Regulation and stability in fish assemblages of neotropical floodplain lakes. Oecologia, 99: 166-180.

Santin, M. 2007. Distribuição temporal e ontogenia alimentar de larvas e juvenis de Pachyurus bonariensis Steindachner, 1879 (Perciformes, Sciaenidae) da baía Sinhá Mariana, rio Cuiabá, Mato Grosso. Unpublished PhD. Thesis, Universidade Estadual de Maringá, Maringá, 32p.

Sanvicente-Añorve, L., C. Flores-Coto \& X. Chiappa-Carrara. 2000. Temporal and spatial scales of the ichthyoplankton distribution in the Southern Gulf of Mexico. Estuarine Coastal and Shelf Science, 51: 463-475.

Sanvicente-Añorve, L., L. A. Soto, M. L. Espinosa-Fuentes \& C. Flores-Coto. 2006. Relationship patterns between ichthyoplankton and zooplankton: a conceptual model. Hydrobiologia, 559: 11-22.

Scheidegger, K. J. \& M. B. Bain. 1995. Larval fish distribution and microhabitat use in free-flowing and regulated rivers. Copeia, 1995(1): 125-135.

Severi, W. 1997. Ecologia do ictioplâncton no Pantanal de Barão de Melgaço, bacia do Rio Cuiabá, Mato Grosso, Brasil. Unpublished PhD. Thesis, Universidade Federal de São Carlos, São Carlos, 260p.

da Silva, C. J. \& F. A. Esteves. 1995. Dinâmica das características limnológicas das baías Porto de Fora e Acurizal (Pantanal de Mato Grosso) em função da variação do nível da água. Oecologia Brasiliensis, 1: 47-60.

Súarez, Y. R., M. Petrere-Júnior \& A. C. Catella. 2004. Factors regulating diversity and abundance of fish communities in Pantanal lagoons, Brazil. Fisheries Management and Ecology, 11: 45-50.

Tanaka, S. 1973. Stock assessment by means of ichthyoplankton surveys. FAO Fisheries Technical Paper, 122: 33-51.

Vazzoler, A. E. A. de M. 1996. Biologia da reprodução de peixes teleósteos: teoria e prática. Maringá, Eduem, 169p.

Vazzoler, A. E. A. de M. \& N. A. Menezes. 1992. Síntese de conhecimento sobre o comportamento reprodutivo dos Characiformes da América do Sul (Teleostei, Ostariophysi). Revista Brasileira de Biologia, 52(4): 627-640

Welcomme, R. L. 1979. Fisheries ecology of floodplain rivers. London, Longman, $317 \mathrm{p}$.
Welcomme, R. L. 1985. River fisheries. FAO Fisheries Technical Paper, 262: 330p.

Wilkinson, L. 1998. Systat - Systems of Statistics. Software. Version 8. Chicago, IL: SPSS Inc. 